\title{
THE INFLUENCE OF CD4+T CELLS, HIV DISEASE STAGE AND ZIDOVUDINE ON HIV ISOLATION IN BAHIA, BRAZIL
}

\author{
Carlos Brites, Célia Pedroso, Nanci Silva, Warren D Johnson Jr and \\ Roberto Badaró
}

\begin{abstract}
HIV-1 isolation was attempted on 72 individuals, including persons with knoun HIV infection and five without proven HIV infection but with indeterminate Western blot patterns, as well as on low-risk HIV seronegative persons. The ability to detect HIV1 from culture supematant by p24 antigen capture assay was evaluated by segregating patients by absolute CD4+ cell counts, clinical stage of disease, p24 antigenemia and zidonudine use. The likelihood of a p24 positive HIV culture was bighest among patients with CD4+ T-cell counts below 200/ul and patients with advanced clinical disease. Use of zidovudine did not affect the rate of HIV positivity in cultures.
\end{abstract}

Key-words: HIV. P24. Viral isolation. Brazil. CD4+ Tlympbocytes

The human immunodeficiency virus Type1 (HIV-1) has been isolated from lymph nodes, peripheral blood mononuclear cells (PBMC), and other body fluids, from patients with HIV infection and/or the acquired immunodeficiency syndrome (AIDS) ${ }^{18}$. Different rates of virus isolation from PBMC of HIV-1 infected patients have been reported, ranging from 30-99\% 71012 . Recent modifications of standard techniques led to the ability to estimate viral load from plasma and PBMC obtained from patients with different stages of HIV-1 infection ${ }^{6}$ ? This method is used to increase understanding of HIV disease progression and to monitor the effect of antiviral therapy.

As of 1993 over 40,000 AIDS cases have been reported in Brazil ${ }^{13}$. This study was initiated to evaluate the qualitative and quantitative HIV cultivation methods and the effect of patients' CD4+ T-cell count, clinical stage of disease, p24 antigenemia and Zidovudine use on recovering $\mathrm{HI}^{\mathrm{V}}$.

\footnotetext{
Laboratório de Retrovírus. Hospital Universitário Prof. Edgard Santos, Universidade Federal da Bahia, Salvador, BA, Brazil, and Division of International Medicine, Cornell University Medical College, New York, NY, USA

Research supported by grants AI26506 and TW00018 from the United States Public Health Service.

Address to correspondence. Dr. C. Brites. Laboratório de Retrovírus/HUPES/UFBA. R. João das Botas s/n, Canela, 40110-160 Salvador, BA, Brazil.

Phone: (55 71) 235-4866, Fax (55-71) 245-7110.

Recebido para publicação em 08/12/94.
}

\section{MATERIAL AND METHODS}

Study Population. Patients attending the AIDS clinic of the Federal University of Bahia Hospital were eligible for the study. PBMC from 72 individuals were cultivated for HIV-1 isolation from the following groups: a) Fiftyone patients with HIV-1 positive Western blot (WB); b) Five low-risk HIV-1-enzyme immunoassay (EIA) reactive blood donors who had an indeterminate HIV-1 WB pattern ( 124 band only); and c) Three HIV-EIA and WBseronegative patients, who were admitted to the hospital with an infection suggesting AIDS. In addition, $13 \mathrm{HIV}$-seronegative health care workers were used as controls. All the participants of the study gave written consent. The 1988 revised criteria from CDC were used for clinical staging of the patient ${ }^{14}$. The study was conducted between March, 1990 and June, 1993

$P B M C$ preparation and viral isolation procedure. Donor PBMC. Twenty milliliters of heparinized ( $20 \mathrm{U}$ of preservative-free heparin $/ \mathrm{ml}$ ) blood were collected from healthy HIV seronegative volunteers and diluted in sterile phosphate buffered saline (1:1). Peripheral blood mononuclear cells (PBMC) separated by Ficoll-Hypaque gradient centrifugation were suspended in sterile RPMI1640 medium (GIBCO Laboratories, Grand Island, New York, NY), containing 15\% fetal calf serum (GIBCO), penicillin $(100 \mathrm{\mu} / \mathrm{ml})$, streptomycin $(10 \mathrm{ug} / \mathrm{ml})$, and $2 \mathrm{mM} \mathrm{L}$ glutamine, and stimulated with $4 \mu \mathrm{g} / \mathrm{ml}$ phytohemaglutinin (PHA, Sigma Co., St. Louis, $\mathrm{MO}$ ) for three or four days at $37^{\circ} \mathrm{C}, 5 \% \mathrm{CO}_{2}$ 
Brites C, Pedroso C, Silta N, Johnson Jr WD, Badaró R. The influence of CD4+ T cells, HIV disease stage and zidoudine in HIV isolation in Babia, Brasil. Revista da Sociedade Brasileira de Medicina Tropical 29:5-9, jan-fel, 1996.

Qualitative and Quantitative cultures. Fifty qualitative cultures were performed in $28 \mathrm{HIV}$ 1 infected individuals, 5 blood donors with indeterminate WB patterns, three HIVseronegative patients, a child of a HIV-infected mother, and 13 seronegative controls. Patient $\operatorname{PBMC}\left(20 \times 10^{\circ}\right.$ cells $)$ were co-cultivated according to standard procedures described elsewhere ${ }^{10}$. The culture supernatants were collected at $3,7,10,14,17$, and 21 days and stored at $-20^{\circ} \mathrm{C}$, for $\mathrm{p} 24$ antigen assays .

Thirty-five quantitative cultures were performed, as previously described by $\mathrm{Ho}$ et $\mathrm{al}^{\prime \prime}$, on $30 \mathrm{HIV}-1$ seropositive individuals (including 8 patients tested by qualitative methods).

Assays for HIV-1 antibodies and $p 24$ antigens. Antibodies against HIV-1 were detected by an enzyme-linked immunosorbent assay (EIA) and confirmed by Western blot (Du Pont Corporation, and Biotech-Dupont, respectively, Willmington, DE, ). The HIV-1 p24 core antigen was assayed in the serum and in culture supernatants by a antigen capture enzyme immunoassay (Abbott Laboratories, North Chicago, IL). A positive culture was defined as either a single p24 antigen concentration $\geq 1000 \mathrm{pg} / \mathrm{ml}, 2$ consecutive samples with a p24 antigen $\geq$ $200 \mathrm{pg} / \mathrm{ml}$, or reactive samples (at least 2 times above the cut off value) neutralized by antip24 monoclonal antibody (Abbott Laboratories).

CD4 cell counts. CD3+, CD4t and CD8+ cells were counted by a standard immunofluorescent method using mouse antihuman monoclonal antibodies (Orthomune $\mathrm{OKT}_{3}, \mathrm{OKT}_{4}$, and $\mathrm{OKT}_{8}$ monoclonal antibodies, Ortho Diagnostic Systems, Raritan, $\mathrm{NJ}$ ). Indirect staining of the lymphocytes with labeled monoclonal antibody was performed using goat anti-mouse Ig-FITC. The lymphocyte subsets were counted using a epifluorescent microscope (Microphot - FXA Nikon Corporation, Tokyo, Japan).
Statistical analysis. Data were entered into EPIINFO version 5.0 and analyzed by Fischer's Exact, Student's t-test, or Kruskall Wallis test.

\section{RESULTS}

Qualitative and Quantitative cultures. Forty-five of $50(90 \%) \mathrm{HIV}-1$ seropositive individuals had at least one positive (qualitative or quantitative) culture for HIV-1. All patients from this group had the usual risk factors associated with AIDS, including unprotected sexual activities with high risk individuals and/or intravenous drug use. The patients consisted of 32 male homo/bisexuals, 10 intravenous drug abusers (IVDA) and 3 heterosexual females with HIV-positive sexual partners. Cultures were negative from five blood donors with indeterminate WB patterns, a child from an HIV-infected mother, and from the 3 seronegative patients. Also, all 13 seronegative healthy controls had negative HIV cultures. Six months after the initial study repeated HIV serology, in the five blood donors with indeterminate WB was negative for 3. Two remained presenting an indeterminate WB pattern for 18 months of follow-up.

Table 1 compares the recovery of HIV by qualitative and quantitative culture methods. There was no significant difference between cultures from the same individual using the qualitative versus the quantitative method. The overall rate of positive HIV cultures for the qualitative and quantitative methods was $81 \%$ and $89 \%$, respectively, excluding the 3 seronegative AIDS patients and the individuals with indeterminate WB.

Correlation of CD4+ T-cell and clinical stage with a positive HIV-1 culture. Higher rate of viral culture positivity was associated with advanced HIV disease. The rate of viral isolation was $60 \%(12 / 20)$ for class II/IVA patients, in contrast to $96 \%(44 / 46)$ for AIDS IV-C patients. The mean CD $4+\mathrm{T}$ cell count

Table - Rates of positivity of qualitative and quantitative cultures for HIV-1.

\begin{tabular}{|c|c|c|c|c|c|c|}
\hline \multirow[t]{2}{*}{ Patients Category } & \multicolumn{2}{|c|}{ Qualitative } & \multicolumn{2}{|c|}{ Quantitative } & \multicolumn{2}{|c|}{ Total } \\
\hline & $n$ & $\%$ & $\mathrm{n}$ & $\%$ & $\mathrm{n}$ & $\%$ \\
\hline CDC Class IV-C AIDS & $20 / 22$ & 91 & $24 / 24$ & 100 & $44 / 46$ & $96 *$ \\
\hline CDC Class II-IV A & $5 / 9$ & 55 & $7 / 11$ & 64 & $12 / 20$ & $60^{*}$ \\
\hline HIV-1 Seronegative & $0 / 3$ & - & 0 & - & 0 & - \\
\hline Individuals with & & & & & & \\
\hline Indeterminate WI3 Pattern & $0 / 5$ & . & () & - & $0 / 5$ & - \\
\hline
\end{tabular}


Brites $C$, Pedroso C, Silva N, Jobnson Jr WD, Badaró R. The influence of CD4+ T cells, HIV disease stage and zidonudine in HIV isolation in Babia, Brasil. Revista da Sociedade Brasileira de Medicina Tropical 29:5-9, jan-fer, 1996.

was $311 \pm 316$ for individuals with positive cultures, and $872 \pm 670$ cells/ $\mu$ l for those with negative results ( $p=0.03$, Kruskall-Wallis test). When the results were analyzed by stratifying CD4+ T-cells counts of $>500,200-500$ and $<$ 200 per $\mu l$, a significant difference was observed between cultures from patients with CD4+ T-cell count levels $>500$ cells $/ \mu$ l and those with $\leq 500 \mathrm{cell} / \mu \mathrm{l}$ (Table 2$)$.

Table 2 -Positivity of HIV-1 cultures and CD4+ cell comts.

\begin{tabular}{|c|c|c|}
\hline \multirow[t]{2}{*}{ CD4 + cell count $/ \mathrm{mm}^{3}$} & \multicolumn{2}{|c|}{ Cultures/Total } \\
\hline & $n$ & $0 / 1 /$ \\
\hline$>500$ & $9 \longdiv { 1 4 }$ & 65 \\
\hline $200-500$ & $12 / 15$ & 80 \\
\hline$<200$ & $25 / 25$ & 100 \\
\hline Total & $46 / 54$ & 85 \\
\hline
\end{tabular}

There was also a significant difference in cultures positivity for patients with CD $4+$ cell counts above and below $500 / 4 l<p=0.02$ Fisher exact test).

The correlation of the titer of infectious HIV-1/10 PBMC, and levels of CD4+ cells in the patients with positive cultures is presented in the Table 3. Previous use of Zidovudine did not appear to alter ability to isolate HIV from patients' PBMC). The rate of positivity was similar for patients using AZT (31/34) and, for individuals who did not use that drug (7/25), regardless the type of culture $(p=0.17$, Fischer exact test).

Viral load also correlated with the level of CD4+ T-cell counts. Individuals with CD4+ counts $>500$ cells $/ \mu l$ had $12 \pm 21$ TCID while those with CD4+ counts $\leq 500$ cells $/ \mu$ had a 35 -fold higher viral burden, $446 \pm 1406$ TCID . It is of note that 2 million PBMC per culture were sufficient to detect HIV by culture in $57 \%$ of individuals with CD4+> 500/pl (Table 4).

Assays for p24 Ag detection were performed in serum samples of 35 individuals (32 seropositive and 3 seronegative for HIV 1 infection). Among the seropositive individuals, $21(66 \%)$ had detectable levels of p24 antigen in their sera. The 3 seronegative patients tested had a negative p24 antigen test. The rate of culture positivity was similar for patients with detectable antigenemia (82\%) or not $(75 \%)$. The frequency of p24 antigenemia was almost two times higher among the AIDS class IV-C patients $(84 \%)$ when compared with the class II/IV-A group (only $48 \%$ had detectable levels of $\mathrm{p} 24$ antigen, $\mathrm{p}=0.009$, Yates corrected).

\section{DISCUSSION}

In the evaluation of qualitative and quantitative culture methods, an overall HIV positivity rate of $85 \%$ was detected in HIVseropositive individuals, with a $60 \%$ culture positivity in less ill HIV-infected individuals (asymptomatic class II/III to IV-A). We were able to detect the virus in $96 \%$ of AIDS patients with stage disease class IV-C. This is comparable to what has been reported in the literature. Quantitative or qualitative methods was not significantly different in their ability to detect HIV-1 in culture.

Table 3-Titers of infectious HIV-1 in 35 cultures of PBMC. mean of CD $4+$ T-Cells and use of zidoutine theraby

\begin{tabular}{|c|c|c|c|c|}
\hline TCID $/ 10^{6} \mathrm{PBMC}$ & Number of cultures & $\%$ & Mean of CD $4+$ cells & Use of zidovudine \\
\hline 0 & 4 & 11 & $907 \pm 542$ & 0 \\
\hline 0.5 & 14 & 40 & $222 \pm 218$ & 7 \\
\hline 5 & 7 & 20 & $314 \pm 340$ & 1 \\
\hline 50 & 5 & 14 & $390 \pm 275$ & 1 \\
\hline 500 & 3 & 9 & $190 \pm 134$ & 0 \\
\hline 5000 & 2 & 6 & $310 \pm 110$ & 1 \\
\hline 50000 & 0 & - & - & - \\
\hline
\end{tabular}

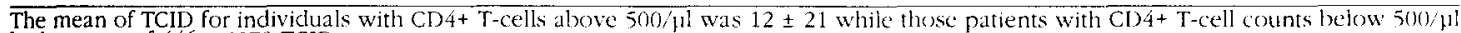
had a mean of $446 \pm 1379$ TCID.

Table 4 - Culture isolation of HIV stratified by CT $4+7-$ cell counts.

\begin{tabular}{|c|c|c|c|c|c|c|c|c|c|c|}
\hline \multirow{3}{*}{ CD4 T-cells per $\mu$ l } & \multicolumn{10}{|c|}{ Dilutions of patient PBMC } \\
\hline & \multicolumn{2}{|c|}{$2 \times 10^{6}$} & \multicolumn{2}{|c|}{$2 \times 10^{5}$} & \multicolumn{2}{|c|}{$2 \times 10^{4}$} & \multicolumn{2}{|c|}{$2 \times 10^{3}$} & \multicolumn{2}{|c|}{$2 \times 10^{2}$} \\
\hline & $\mathrm{n}$ & $\%$ & $\mathrm{n}$ & $\%$ & $n$ & $\%$ & $\mathrm{n}$ & $\%$ & $\mathrm{n}$ & $\%$ \\
\hline 50 & $4 / 7$ & 57 & $1 / 7$ & 29 & $2 / 7$ & 17 & $0 / 7$ & 0 & $0 / 7$ & (i) \\
\hline $200-500$ & $11 / 12$ & 92 & $8 / 12$ & 67 & $3: 12$ & 25 & $3 / 12$ & 25 & $1 / 12$ & 8 \\
\hline 200 & $13 / 13$ & 100 & $5 / 13$ & 38 & $2 / 13$ & 15 & $0 / 13$ & 0 & $1 / 13$ & 8 \\
\hline Total & $28 / 32$ & 88 & $15 / 32$ & 47 & $7 / 32$ & 22 & $2 / 32$ & 6 & $2 / 32$ & 6 \\
\hline
\end{tabular}

Foot notes: Mean ( \pm SD) CD $4+$ T-cell counts of individuals with a positive and negative viral culture were $311 \pm 316 / \mu l$ and $812 \pm 620 / \mu 1$ Foot notes: Mean $( \pm$ SD) $C D 4+1-$ cell counts
$(\mathbf{P}=0.03$, Kruskall Wallis test). respectively. 
Brites C, Pedroso C, Silta N. Johnson Jr WD, Badaró R. The influence of CD4+ T cells, HIV disease stage an zidurudine in HIV isolation in Babia, Brasil. Revista da Sociedade Brasileira de Medicina Tropical 29:5jan-fet: 1996.

Patients with CD4+ T-cell counts $\leq 500 / \mu l$ are more likely than those with $>500 / 1$ to have a positive viral culture. Individuals with a negative HIV culture had a mean CD $4+$ T-cell count that was three times higher than that of patients with positive HIV culture. Our results were similar to those reported by Spira and Burke ${ }^{15}$. The level of CD4+ T-cells in ability to culture HIV from patient PBMC probably reflects the higher viral burden in patients with more advanced HIV disease. This is suggested by our data and by others" "15. Thus, the sensitivity for detecting HIV by culture for patients with less advanced HIV infection and AIDS is 60\% and 96\%, respectively. Viral cultures were negative for HIV-seronegative individuals, and in five low risk blood donors with an indeterminate WB. According to other studies" ${ }^{\text {" }}$ this would suggest that they were not infected. The lack of false positives from cultures obtained from these HIV-seronegative or indeterminant WB individuals indicates that the specificity of culture methods is $100 \%$.

In our experience the positivity of cultures was not affected by zidovudine use, as previously observed ${ }^{2}$. Among the patients using zidovudine and having positive quantitative culture, 8 had a TCID of $\leq 5$, while only 2 had a higher level of infection.

In conclusion, the viral isolation from HIV1 infected patients in our study showed a sensitivity similar to those reported in the literature. However, the higher CD4+ T-cell counts in the individuals with negative cultures explain the lower rate of viral isolation in the less ill HIV infected individuals compared to the higher rate in AIDS class IV-C patients.

\section{RESUMO}

Tentativa de isolamento do lirus tipo 1 da imunodeficiência adquirida (VIH-1) foi realizada em 72 inditiduos sendo 51 pacientes $\mathrm{com}$ sorologia positita para o VH-1, confirmada por Western blot; 5 doadores de sangue com padrão indeterminado ao Western blot; 3 individuos com diagnóstico clínico de AIDS, porém com sorologia negatian, e 13 profissionais de saüde soronegativos. Os pacientes foram estratificados de acordo com a contagem de células CD4t, estágio clinico. antigenemia (p24) e uso de zidonudine. As culturas para o VH-1 foram positias em 45/50 (90\%) tentaticas. Houne uma correlação inversa entre o mímero de células $C D 4+$ e a frequência de isolamento do VH-1. As culturas foram positivas em $84 \%$ dos inditiduos com CD4t $<200$, contra $48 \% d$ positividade naqueles com contagem de célula CDÁ acima deste valor: O uso de zidonudine nä interferin na positividade das culturas. Concluímo. que a sensibilidade dos métodos de culture qualitatio e quantitatizo é similar para a deteccaic do VH-1. A taxa de posititidade das culturas hã foi afetada pelo uso prétio de zidorudine, mas foi diretamente proporcional ao grau de immodeficiencia dos pacientes.

Palaras-chaves: VIH. p24. Isolamento viral. Brasil. CD4+ linfócitos $T$ :

\section{ACKNOWLEDGMENT}

We thank Dr. Robert Akridge for his critical review of the paper, and Zacarias A. Santana Jr. for the computer and editorial assistence of this manuscript.

\section{REFERENCES}

1. Barré-Sinoussi F, Chermann JC, Rey F, Nugeyre MT, Chamaret S, Gurest J, Danguet C, Axler-Blin C, Brun-Vézinet $F$, Rozembaum $W$, Montagnier $L$. Isolation of a T-lymphotropic Retrovirus from a Patient at Risk for Acquired Immune Deficiency Syndrome (AIDS). Science 220:868-71, 1983

2. Gallo RC, Sarin PS, Gelmann EP, Robert-Guroff $M$, Richardsön E, Kalyanaraman VS, Mann D, Sidhu GD, Stahl RE, Zolla-Paznes S, Leibowitch J, Popovic M. Isolation of Human T-Cell Leukemia Virus in Acquired Immune Deficiency Syndrome (AIDS). Science, 220:865-8 1983.

3. Gallo RC, Salahuddin SZ, Popovic M, Shearer GM, Kaplan M, Haynes BF, Palkert J, Redfield R, Oleske J, Safai B, White G, Foster P, Markham PD. Frequent Detection and Isolation of Cytopathic Retroviruses (HTLV-III) from Patients with AIDS and at Risk of AIDS. Science 224:500-3, 1984.

4. Levy JA, Hoffman AD, Kramer SM, Landis JA, Schimabukuro JM, Oshiro LS. Isolation of Lymphocytopathic Retroviruses from San Francisco Patients with AIDS. Science 225:840-2, 1984 ,

5. Jackson JB, Coombs RW, Sannerud K, Rhame FS, Balfour HH Jr. Rapid and Sensitive Viral Culture Method for Human Immunodeficiency Virus Type 1. Journal of Clinical Microbiology 26:1416-8, 1988.

6. Castro BA, Weiss CD, Wiviott LD, Levy JA. Optimal Conditions for Recovering Human Immunodeficiency Virus from Peripheral Blood Mononuclear Cells. Journal of Clinical Microbiology 26:2371-6, 1988. 
Brites C, Pedroso C, Silla $N$, Jobnison $\mathrm{Jr} W D$, Badaró $R$. The influence of CD4+ T cells, HIV disease stage and zidotudine in HIV isolation in Babia, Brasil. Revista da Sociedade Brasileira de Medicina Tropical 29:5-9, jan-fen, 1996.

7. Coombs RW; Collier AC; Allain JP; Nikora B; Leuther M; Gjerset GF; Corey L. Plasma viremia in Human Immunodeficiency Virus Infection. New England Journal of Medicine 321:1626-31, 1989.

8. Ho DD, Moudgil T, Alam M. Quantitation of Human Immunodeficiency Virus Type 1 in the Blood of Infected Persons. New England Journal of Medicine 321: 1621-1625, 1989.

9. Ministério de Saúde. AIDS - Boletim Epidemiológico, ano VI, $\mathbf{n}^{\circ}$ 08, 1993.

10. Revision of the CDC Surveillance Case Definition for Acquired Immunodeficiency Syndrome. Mortality and Morbidity Weekly Report 36(suppl 1):3S-15S, 1987.

11. Spira TJ, Kaplan JE, Feorino PM, Warfield DT, Fishbein DB, Bozeman LH. Human Immunodeficiency Virus Viremia as a Prognostic Indicator in Homosexual Men with Lymphadenopathy Syndrome. New England Journal of Medicine 317:1093-4, 1987.

12. Burke DS, Fowler AK, Redfield RR, Dilworth S, Oster CN. Isolation of HIV-1 from the Blood of
Seropositive Adults: Patients Stage of Illness and Sample Inoculum Size are Major Determinants of a Positive Culture. Journal of Acquired Immune Deficiency Syndrome 3:1159-1167, 1990.

13. Jackson JB, Mac Donald KL, Cadwell J, Sullivan C, Kline WE, Hanson M, Sannerud KJ, Stramer SL, Fildes NJ, Kwok SY. Absence of HIV Infection in Blood Donors with Indeterminate Western blot Test for Antibody to HIV1. New England Journal of Medicine 332:217-222, 1990.

14. Celum CL, Coombs RW, Lafferty W., Inui TS, Louie PH, Gates CA, McCreedy BJ, Egan R, Grove T, Alexander $S$. Indeterminate Human Immunodeficiency Virus Type 1 Western Blots: Seroconversion Risk, Specificity of Supplemental Test, and an Algorithm for Evaluation. Journal of Infectious Diseases 164: 656-64, 1991.

15. Burke DS, Redfield RR, Bjornson DC, Fowler AK, Oster $\mathrm{CN}$. Frequent Isolation of HIV1 from the Blood of Patients Receiving Zidovudine (AZT) therapy. New England Journal of Medicine $321: 1682,1989$. 